\title{
3. The Military in Post-Colonial Fiji
}

\author{
Jone Baledrokadroka
}

\section{Les militaires dans les Fidji à l'époque postcoloniale}

Les militaires à Fidji sont devenus une institution omniprésente de la politique au sein de l'Etat. Leur rôle traditionnel a fusionné avec un rôle de sécurité humaine politiquement nuancé. L'instabilité politique actuelle à Fidji est liée à l'expansion du rôle des militaires depuis l'indépendance, marquée par un accent trop fort mis sur les activités non fondamentales comme la création d'un Etat, le maintien de l'ordre et la sécurité intérieure. Ceci a eu un effet délétère sur la stabilité politique $\mathrm{du}$ pays. Cet article propose une explication de l'intervention des militaires dans la politique à Fidji de façon si continue depuis 1987. Un point de discussion dans ce débat met l'accent sur l'importance de l'héritage colonial et l'image que les militaires ont d'eux-mêmes qui a été encouragée pendant la période coloniale. Un autre montre la faible division du travail dans les Etats-nations émergents et la façon dont ceci peut exacerber les divisions ethniques qui conduisent les militaires à assumer un rôle de médiation et à créer un Etat qui a tendance à connaître des coups d'Etat ou à être un Etat prétorien. D'après de nombreuses personnes, dans les pays nouvellement indépendants, « la réaction négative contre l'incompétence des civils et la corruption » a souvent justifié l'intervention des forces militaires. Le commodore Bainimarama a maintes fois invoqué cette excuse pour justifier son coup d'Etat destiné à réaliser un nettoyage. Cet article affirme que l'intérêt des militaires en tant que corporation tient un rôle de premier plan dans le calcul que fait une élite militaire en faveur de l'intervention et que le nouveau « professionnalisme » militaire dans les pays du Tiers-Monde comme le Brésil, la Birmanie, la Thaïlande, le Nigéria, l'Indonésie et Fidji s'exprime dans la capacité des militaires à assumer un rôle politisé, à tenir les rênes du pouvoir de l'Etat et dominer les institutions de façon provisoire ou permanente.

\section{Introduction}

Fiji's military has become an all pervasive institution of politics in the small Pacific island nation state. The military's traditional hard security role has merged with a politically nuanced human security role. The present state of 
Politics, Development and Security in Oceania

Fiji's political instability is related to the role expansion of Fiji's military since Independence. The expansion has been marked by an over-emphasis on noncore activities such as nation building, peacekeeping and internal security. This has had a deleterious effect on the political stability of the nation.

Why and how has this development taken place? Since cession in 1874 the patriotic adage of For God, King and Country was grafted onto and sat well with Fiji's traditional society. The three central ethos of the British Empire's imperial slogan were integrated into Fijian society as the Lotu, Vanua kei na Matanitu. In the 96 years of British rule this slogan underpinned the colony's military service through two world wars and the Malayan Communist emergency campaign in the 1950's. After Independence Fiji's civil military relations pattern was a hybrid between the traditional aristocratic and liberal democratic model (Nordlinger 1977: 11-13). This hybrid pattern cohered well since independence with the ruling Fijian elite in the form of the Alliance party government of Ratu Sir Kamisese Mara.

\section{Upsizing the Military}

Since the mid seventies the military was increasingly used by the Alliance government under Ratu Sir Kamisese Mara in a nation building role. The raising of the Trade Training School in 1974, the Engineers Rural Development Unit and the Naval Division in 1975 saw the military increase to over three times its size.

In 1978, with Fiji's first deployment of troops with the United Nations interim forces in Lebanon, peacekeeping became a force determinant. A detachment was sent to Zimbabwe in 1980 and in 1982 another Battalion was raised as part of the Multinational Forces and Observers in Sinai Egypt to monitor the IsraeliEgyptian peace accord. This new role increased numbers to over 2000 regular force soldiers by 1982. All during this expansion period recruitment was always kept at over 95 per cent ethnic Fijian. The huge ethnic recruitment numbers disparity was simply put down to the unappealing nature of soldiering to IndoFijian. In retrospect a quota system of recruitment should have been done to even up the ethnic numbers.

Unfortunately this heavily skewed ethnic recruitment only 'reinforced tacit ethnic elitist political association within the institution'. Being overwhelmingly ethnic Fijian the military was always to be a bastion of indigenous political paramountcy. In fact during the March 1977 elections (the second since independence) where the Indian dominated NFP party had won by the slightest majority but were unable to form a government the military was put on alert. 
The question still remains today, what would have happened had not the Governor General, Ratu Sir George Cakobau, appointed Ratu Sir Kamisese Mara to form a minority government.

The three major troop number increases were brought about by local and international political expediency rather than in response to any clear defence role. Hence Nation Building; Peacekeeping and Internal Security became the force determinant for the military.

International peacekeeping exposure to the world's hot spots, especially the Middle East, has imbued a confident political mediator mindset amongst Fiji's military officers.

\section{Part of the Political Elite}

With the 1987 Rabuka coup many of the senior officers became entwined with the Fijian political elite. Rabuka's coup shattered the Westminster civil-military relations ethos and explicitly unveiled the fragile nature of Fijian democracy since Independence. It seemed the Westminster model only lasted so long as government was made up of the Fijian political elite.

With Bainimarama recently emphasising 'only the military can bring about change' the political role of the military persists. The militarisation of government since is real evidence of this politicised role. Over 40 military officers are still holding important government posts from Prime Minister, Cabinet ministers, Permanent Secretaries and other postings on boards of various statutory bodies.

In a parallel development since 1998 the recruitment of over 2,000 Fiji citizens for service with the British armed forces has been ongoing. This has had significant economic and social implications for Fiji with remittances reaching an all time high of more than F300million in 2005.

The third factor that increased military numbers was the internal security role that evolved out of the 1987 coup. The size of the military reached 3,600 in December of 1988 (Fraenkel, Firth \& Lal 2009: 119). The army raised the number of infantry battalions and the number of soldiers in each battalion to 'effectively control' the emergency situation, although many saw that emergency as being one that the RFMF had created in the first place. An elite counter revolutionary warfare unit was formed to protect against government armed insurgency.

As a consequence of executing a supremacist coup in 1987 against a phantom internal security threat, the military in a convoluted way created for itself an 
Politics, Development and Security in Oceania

internal security role previously the ambit of the Fiji Police Force. Ironically in taking upon itself the IS role, like scores of developing countries in the 1960s and 1970s, Fiji is now a coup-prone state.

\section{Why Coups Happen}

In many post-colonial states, civil supremacy under the aegis of democracy is often threatened by the military's colonially-inherited legacies. Often, such societies are troubled by severe schisms of a regional or ethnic character. The military, however, acquires a colonially-induced unifying function. And that given its self image as leading nationalists the military is commonly able to rationalise away or sincerely justify their predatory actions. Since they identify with the nation what is to the advantage of the military is also good for the country. It is almost as if coups promote the national interest.

Western military ethics stress the supremacy of society over the individual, tribe or sub-group, and the importance of order, hierarchy, and division of function in the service of the nation state. Foremost of this military colonial legacy is the principle that the military commander must never allow his military judgement to be warped by political expediency (Huntington 1957: 71). Unfortunately this principle has been compromised as in the Nigeria and Fiji coups with highly professional armies that are drawn from one predominant ethnic group and do not reflect a unified nation. If governments seem captives of those sub-national forces, the incentive for military intervention may become strong.

The degree to which corruption is itself a major cause of military coups is however open to question. Despite its prominence in post coup rationalisations, one might suspect that it is a secondary cause in most cases. Perhaps more significant is military leaders' distaste for the messiness of politics - whether honest or not - and a tendency to blame civilian politicians for failure to meet overly optimistic popular aspirations which would be impossible of fulfilment even by a government of angels (Nye 1967: 422). Again this type of thinking may be the result of the realist and rather simplistic mindset prevalent in military leaders that resorts to coercion in dealing with political evils. For the military view of man is decidedly pessimistic and that the man of the military ethic is essentially the man of Hobbes (Huntington 1957: 63). Bainimarama's 2006 'clean up' or good governance coup rhetoric played to such sweeping justification and an instrumentalist view.

On the other hand military intervention into civilian affairs is not precipitated solely by military groups or elites. Amos Perlmutter found that in most cases civilians turn to the military for political support when civilian political structures and institutions fail or when constitutional means for the conduct 
of political action are lacking (Perlmutter 1969: 390). The civilians begin to form interventionist coalitions or indoctrinate the military with their political ideologies. Several examples of this process can be found in the Middle East and Latin America and recently in Fiji. Secondly, Perlmutter also found that 'corporatism is a prima facia case for interventionism and that professionalism is only one guarantor of non- intervention' (Perlmutter 1981: 2). This appears to be the case in Fiji prior to the 2006 coup. The commissioning of a security review white paper by the SDL Government in 2003 further undermined the fragile relations with the Military Commander. The paper recommended among others a fifty per cent cut in numbers of the Fiji Military Forces and a change to the selection process for the Commanders position. The Fiji military though a considerably small force consisted of a highly professional officer corps - a credit to its British military legacy. Since independence the traditional aristocratic-liberal democratic pattern of civil military relations worked well enough (Nordlinger 1977: 11-15). However this did not stop the RFMF from overtaking democratically elected governments in 1987, 2000 and 2006. One way to look at the driving forces of military intervention or non-intervention is through Finer's disposition/opportunity theory.

In his disposition and opportunity theory, Finer identifies the disposition of the military elite - which is bound to its corporate and individual interests as the push factor. The pull factor is the opportunity that the political 'crisis' offers as a key condition for a military political intervention. According to Finer's calculus of intervention the subjective military disposition factor and the objective opportunity factor acting in unison are the most relevant triggers to the likelihood of a coup. The pre-coup interventionist coalitions of Rabuka and the Taukei Movement in 1987, Speight and Nationalist politicians in 2000 and Bainimarama and the Labour Party in 2006 reinforces this point.

\section{Conclusion}

One theme in this debate over why coups happen emphasises the importance of the colonial legacy, and the military self-image fostered during the colonial period. Another points to the weak division of labour in emerging nation states and the way in which it may exacerbate ethnic divisions that give rise to the military taking over in a mediator role and creating a coup prone or praetorian state. 'Revulsion against civilian incompetence and corruption', as many have argued, is a frequent justification for intervention by military forces in newly independent states. Commodore Bainimarama has often used this excuse for his 'clean-up coup'. 
I have argued that military corporate interest is foremost in a military elite's calculus for intervention. In many Third World countries military 'professionalism' has come to mean not Huntington's old professionalism of external defence, meaning that a professional armed force is one that is subject to civilian authority; but something quite different. The new professionalism in Third World countries such as Brazil, Burma, Thailand, Nigeria, Indonesia and Fiji is expressed in the capacity of the military to assume a politicised role and, either temporarily or permanently, to take the reins of state power and dominate government. Finer takes the argument further in two ways: his disposition and opportunity theory offers an explanation of the push-pull factors that cause the military to intervene in politics; and he suggests an ascending scale of modes of military intervention in politics from working through constitutional channels to overthrowing civilian governments.

In this paper I have endeavoured to explain that the military forces have intervened in Fiji's politics so consistently since 1987 as a result of their non-core-role expansion; the extent to which Fiji exemplifies wider patterns of intervention found elsewhere; the form which intervention has taken at different stages of this story; and the reason for the absolutist character of the intervention that began with the 2006 coup.

\section{References}

Fraenkel, J., Firth, S., \& Lal, B. 2009. The 2006 Military Takeover in Fiji: A Coup to End All Coups? Canberra: ANU E Press.

Huntington, S. 1957. The Soldier and the State: The Theory and Politics of CivilMilitary Relations. Cambridge: Belknap Press of Harvard University Press.

Nordlinger, E. 1977. Soldiers in Politics: Military Coups and Governments. Englewood Cliffs N.J: Prentice Hall.

Nye, J. 1967. 'Corruption and Political Development: A Cost-benefit Analysis'. American Political Science Review. 61(2): 417-427.

Perlmutter, A. 1969. 'The Praetorian State and The Praetorian Army. Toward a Taxonomy of Civil Military Relations in Developing Polities'. Comparative Politics. 1(3): 382-404.

Perlmutter, A. 1981. Political Role and Military Leaders. London: Frank Cass. 